\title{
The New Geography of Global Civil Society: NGOs in the World City Network
}

\author{
PETER J. TAYLOR \\ Loughborough University and Virginia Tech
}

\begin{abstract}
Recent research on the geography of NGOs in Global Civil Society yearbooks has emphasized a north-west European bias. This has been taken to imply that global civil society is but a pale geographical shadow of the power concentrations in global economy and governance. Using an interlocking network model and data on 74 global NGOs with offices across 178 cities, NGO connectivity values for cities show that there is a 'global South', especially sub-Saharan African, geographical bias. Nairobi is the most connected world city with respect to NGO activities. This marked contrast to recent received wisdom implies a diffuse network power relationship. To the extent that global NGOs reveal the new geography of global civil society in a space of flows, these results support a positive interpretation for NGOs contributing to an emancipatory global agenda.
\end{abstract}

In the first yearbook of Global Civil Society (Anheier et al., 2001a) the geography of its subject is given prominence. In the introductory chapter, the editors note that 'in particular, one of the most striking findings of the Yearbook is that global civil society is heavily concentrated in north-western Europe' (Anheier et al., 2001b, p. 7 [emphasis original]). They illustrate this with a table that identifies the top countries that are the 'focal points' of globalization, international rule of law and global civil society (Anheier et al., 2001b, pp. 8-9). Three indices of each category are included and the 11 countries that appear in six or more lists are highlighted: Austria, Denmark, Finland, Germany, Iceland, Luxembourg, Netherlands, Norway, Sweden, Switzerland and the UK. The 'heavily concentrated' geography could hardly be more clear-cut. But is it? Is this the right 'space' for measuring these activities? In Castells's (1996) terminology, is this 'space of places' — countries—really how geographical focal points should be identified?

Correspondence Address: Peter J. Taylor, Department of Geography, Loughborough University, Loughborough LE11 3TU, UK and The Metropolitan Institute at Virginia Tech, 1021 Prince Street, Suite 100, Alexandria, VA 22314, USA. 
A preliminary answer to this question is provided by scrutinising Anheier et al.'s (2001b, p. 9) list of NGO host countries in which Belgium is ranked first in terms of NGO density per million of population. ${ }^{1}$ Why Belgium? It is not necessary to go back to the original data to realize that the process operating here is a desire of NGOs to be in and around Brussels, not because it is in Belgium but because it is the political and administrative center of the EU. Clearly it is the city that is the attraction, not the country. In general, it can be noted that it is cities as coordinators of 'spaces of flows' (Castells, 1996) rather than countries that constitute geographical 'focal points'. In the second Global Civil Society yearbook (Glasius et al., 2002), Sassen (2002) makes the case for a city-centerd interpretation of global civil society and her approach is developed in some detail in this article. Specifically, the global location strategies of a large number of NGOs are measured and analyzed within the framework of the contemporary world city network. The argument is that NGOs as major constituents of the global civil society organize their activities through cities across the world thus creating their particular space of flows through the world city network (Taylor, 2004). In this way we investigate the claim of a 'north-western European concentration' in the context of a new global space of flows.

The basic finding of this article is that the geography of NGOs is more global than previous studies have led us to expect. Thus global civil society does not replicate the geography of economic globalization; it is creating its own new geography. This revision of received wisdom on the geography of global civil society is based upon a new methodology that focuses upon the networks of NGO activities across cities: NGOs are treated as one of the makers of the contemporary world city network (Taylor, 2004). The credibility of the revised geography is grounded in the integration of a formal network model specification with large-scale data collection. Thus it is with these items that we begin before presentation and discussion of the new and surprising results.

\section{NGOs and Global Civil Society}

Although it is commonly agreed that global civil society is a 'fuzzy concept' (Anheier et al., 2001b, p. 11; An-Na'im, 2002; Chandhoke, 2002) with its 'organizational infrastructure' still in a 'state of flux' (Anheier and Themudo, 2002, p. 191), nevertheless Keane's (2001, p. 23) description provides the essence of the subject: 'Global civil society is a vast, interconnected, and multilayered social space that comprises many hundreds of self-directing or non-governmental institutions and ways of life'. Through its 'cross border networks' global civil society is constituted of 'chains of interactions linking the local, regional and planetary orders' (p. 24), This new social world is constituted by 'networks, coalitions, partnerships and social movements' (Anheier and Themudo, 2002).

This article provides an appropriate depiction of the geography of social activities in contemporary globalization. This is a necessary starting point for interpreting global civil society and its relations to other aspects of globalization. We achieve this through a large empirical study of NGOs since these have come to be identified with global civil society-in Chandhoke's (2002, p. 38) words, 'NGOs play a large-than-life role in global civil society'. So much so that it is often found to be necessary to proffer a reminder that global civil society is actually more than the activities of just NGOs (e.g. Anheier et al., 2001b, p. 4; Chandkoke, 2002, p. 38; Anheier and Themudo, 2002, p. 191; Kaldor, 2003). While accepting the latter, NGOs remain the obvious foundation for describing the geography of global civil society and thus will feature as the institutions we measure and analyze below. 


\section{NGOs in a Global Space of Flows}

This essay began with reference to the geography of concentration identified in the introduction to the first Global Civil Society yearbook; this geography appears several times in the arguments of subsequent authors (Glasius and Kaldor, 2002, p. 4; Chandhoke, 2002, p. 37; An-Na'im, 2002 , p. 57). Confirming the importance of geography, it is An-Na'im (2002, pp. 56-7) who spells out why this should be. He argues that the physical location of interactions within global civil society is vital because this reflects power relations, in particular the ability to set policy agendas. Thus the fact that north western Europe is the most secular region in the world will likely produce a global civil society in which the world's major religions, that dominate all other regions, are not adequately or equitable recognized.

But this argument does not tell us what form of space constitutes the new geography of global civil society. If globalization is premised on large-scale transnational processes, as argued above, then territorial frameworks-states-are hardly appropriate units for reporting (Anheier, 2001). In NGO activities, sovereign territories have to be taken into account, but the essence of their operations is their freedom from such boundary restrictions. As we have seen, NGOs are creating a global civil society through myriad networks.

The appropriate spatial framework for understanding NGOs has been provided by Castells (1996) with his concept of a space of flows. He argues that from the 1970s a new network society has emerged based upon the enabling technologies that have resulted from the merging of computing and communication industries. This has created a new type of space because social relations no longer depend upon spatial contiguity. With the new technologies social activities can be organized simultaneously across the world thus opening up new spaces of flows. In network society, the latter dominate the old spaces of places (such as states) because they provide a flexibility in activity that can simply by-pass fixed assets in territories. Castells describes his space of flows at several levels starting with the infrastructural level (wires, satellites and electronic pulses). Most social activity occurs in Castells's second level of 'nodes and hubs' through which transnational social organization is constructed. Thus there are global networks of medical researchers sharing projects but located in separate nodes (e.g. Rochester, New York and Paris) but who communicate electronically with each other incessantly, while meeting regularly at international conferences (hubs).

The institutions that have taken most advantage of the infrastructure level are, of course, MNCs (multinational corporations), now often referred to as global corporations. They have developed worldwide networks of production and marketing that have revolutionized economic geography (Dicken, 2003). However, Townsend (1999, p. 613) has argued that NGOs are 'quite as transnational as Exxon'. Leading NGO operatives are equally part of what Pijl (1998) has called a 'transnational class' (Townsend et al., 2002, p. 830). The result is that, 'as in the business sphere, fads sweep the world; microcredit is almost as placeless as just-in-time production' (Townsend, 1999, p. 616). Thus although the circuits of flows are through different networks, NGOs and MNCs are both integral to the same overall global space of flows that defines contemporary globalization.

\section{NGO Organization and Cities: An Interlocking Network Model}

Castells (1996, p. 415) identifies Sassen's (1991) work on the global city as the 'most direct illustration' of the nodes and hubs social layer in the space of flows. Her research identifies the production and provision of advanced producer services (financial and business services) 
as key practices producing global cities. These service firms, MNCs in their own right, provide specialist services to other corporations and governments across the world through their professional knowledge and creative practitioners in such complex areas as multi-market advertising and trans-jurisdictional law. Sassen focuses on the major global cities but Castells emphasizes the fact the network connections are not limited to just a few 'top cities'. Rather there is a world city network of global service centers that produce and distribute advanced services across the world (Taylor, 2001).

Sassen (1994) has argued that cities constitute strategic places in the development of a new world geography. Recently she has transferred this argument from the global services market to global civil society (Sassen, 2002). Thus the 'strategic cross border geography that bypasses national states' is part of 'the infrastructure of global civil society' (Sassen, 2002, p. 217). This is because cities provide a 'thick enabling environment' (Ibid., p. 217) through which transnational and sub-national activities can be brought together: 'The density of political and civic cultures in large cities localises global civil society in people's lives. We can think of these as multiple localisations of civil society that are global in that they are part of global circuits and transboundary networks' (Sassen, 2002, p. 218).

Hence she is able to argue that a 'focus on cities allows us to capture, not only the upper, but also the lower circuits of globalisation' (Sassen, 2002, p. 219). I build upon this very powerful argument here.

Neither Castells or Sassen, nor indeed the world cities literature in general, have specified the exact nature of the worldwide networks that they frequently invoke (Taylor, 2004). This has meant that it has not been possible to measure and analyze the networks empirically until quite recently. However, recent specification of the world city network as an interlocking network has opened up new analytical possibilities (Taylor, 2001). Interlocking networks have three levels instead of the usual two: as well as the network and nodal levels, there is a subnodal level. In the case of the world city network, drawing on Sassen's early work, the subnodal is occupied by advanced producer service firms who 'interlock' cities through their large office networks in major cities throughout the world. Initially service firms followed their globalizing clients to keep their business but subsequently they have developed their own global location strategies to offer a global 'seamless' service (thus preserving their brand image) and attract new clients in worldwide markets. Hence it is the global service firms that are the creators of the world city network: they 'interlock' cities through their everyday practices. It is the myriad intra-firm flows - of information, knowledge, direction, advice, plans, strategy, personnel, etc.-between the archetypal high-rise offices of global advertising, accountancy, banking, insurance, law, management consultancy and other service sector firms within cities that constitute the world city network. It is this interlocking network model that can be employed to study global civil society: we replace global service firms by global NGOs. The latter are interpreted as another set of world city network makers. This is formally specified in Appendix A.

The basic advantage of using an interlocking network model to conceptualize global civil society is that it provides a rigorous means of assessing the importance of cities within the network. Instead of simply counting up the number of NGOs located in a city, with this model we can measure the connectivity of a city within the network. Using information on the importance of NGO offices in a city, we can show how well linked that city is to other cities through the NGO offices it houses. The basic premise is that the more important an office is, the more flows it generates into and out of its city. Thus a city will be highly connected in the network if it houses a lot of important NGO offices and those offices are themselves part of large office networks (i.e. the NGO has offices in a large number of cities across the world). 
Hence it can happen that a city housing a large number of NGO offices may not be very well connected within the network if its NGOs are typically part of small NGO office networks. These measures are termed NGO network connectivities and are defined in Appendix A.

Note that, following interlocking model for service firms, it is only intra-NGO flows that are considered. There may be fewer pressures for non-commercial entities such as NGOs to favor internal over external contacts in their everyday projects, and this should kept in mind in this model transfer from one field of activity to another.

\section{Operationalizing the Model: Data Collection}

For Townsend (1999, p. 617) the NGO community is a 'puzzle' because despite much research on specific NGOs, projects and themes, 'one dimension is missing': 'global maps of flows' within the NGO community. The reason for this research lacuna is spelt out clearly by Anheier (2001). He identifies the culprit as 'methodological nationalism': 'The current "statistical world order" continues to assume equivalence between nation state, domestic economy, and national society. This equivalence is fundamentally challenged by globalization' (Anheier, 2001, p. 221).

This geographical co-incidence assumption is the embedded statism endemic to macro-social science that is reliant on 'state-istics' (Taylor, 2003). According to Anheier (2001, p. 222) it has led to NGOs being 'treated as domestic agents for measurement purposes, therefore losing an essential aspect of their very raison d'etre'. However, in his quest to measure global civil society using official data Anheier (2001, p. 223) is forced to concede that the country becomes the de facto unit of analysis'. Hence the data in the first Global Civil Society yearbook (Anheier et al., 2001a) are overwhelmingly about states, which is both unsatisfactory and very disappointing.

Obviously the answer to this problem is not to rely on official statistics. A beginning is made along this alternative route in the second Global Civil Society yearbook (Glasius et al., 2002). The new data come in two forms. First, a ranking of cities in terms of numbers of NGOs present is provided by Glasius and Kaldor (2002, p. 6) which, they point out (2002, p. 4), again emphasizes the dominance of Europe (Brussels is ranked first and there are 12 further European cities in the top 20). This aggregate data is interesting but does not inform us about NGO networks. Second, networks are to be found in the yearbook's data sets where information about states is augmented by four maps of 'global networks'. However, here we are back to specific cases, interesting but providing no general guide to NGO networks across the world. In the analyses presented below these two forms of data are combined to create aggregate measurements of networks. This is made possible by the precise specification of the interlocking network model. A key advantage of this specification is that it directs data collection to enable empirical description and analysis of the new geography.

The data requirement is to construct a data matrix of NGOs and cities as an array of 'NGO activity values'. This requires gathering information on the office networks of a large number of NGOs, recording their city locations, and assessing the importance of each office to create 'activity values'. This data collection exercise was conducted as follows:

1. Selecting NGO categories. Using the Yearbook of International Organizations (2001-2002) four subject categories were chosen: environment, development, human rights and humanitarian. These were selected as defining 'social movement NGOs', considered particularly relevant to the development of global civil society. 
2. Selecting global NGOs. A non-systematic selection of 200 NGOs from each category was initially made. These 800 NGOs were inspected for the geographical scope of their offices. To qualify as 'global NGOs', they had to have offices in at least three continents. 86 were found to fit the criterion.

3. Defining office activity values. The web sites of the 86 NGOs were scrutinized for information on the role and functions of their offices. Insufficient information was available for 12 NGOs and these were eliminated from the study. For the final selection of 74 NGOs, offices were scored in terms of their organizational scope: international headquarters score 4, regional offices score 3. national offices score 2, and 'sub-state' offices score 1. The resulting scoring covered offices in 603 cities and towns across the world.

4. Selecting the cities. Most of the 603 locations had minimal NGO presence. These were eliminated by adding the scores for each city and town, and then dropping all places with sums of 4 or below. Obviously such places have just one or two minor offices and can be considered unimportant for defining the NGO city network. This left a total of 178 cities.

The end result is a matrix defined by 178 cities and 74 NGOs (listed in Appendix B). The resulting array consists of 13,172 (i.e. $178 \times 74$ ) 'activity values' range from 0 (no presence of an NGO in a city) to 4 , where each cell indicates the importance of a given city to the office network of a given NGO. Hence, every column describes a simple coding list of an NGO's office location strategy, and every row describes a simple coding list of the mix of NGO offices in a particular city. This is the NGO activities value matrix in the specification of an interlocking network model (Appendix A) operationalized for empirical analysis.

\section{City Connectivities in Global Civil Society}

The most elementary way of defining the geography of global civil society with the new data is to look at the distribution of the 178 cities across major world regions. This simple exercise provides the first evidence that the European concentration, so emphasized in previous discussions of the geography of global civil society, is not replicated in this study. Sub-Saharan Africa with 40 cities is the leading region featured in our data, followed by Latin America (31 cities). Western Europe does appear in third place with 26 cities and certainly is far ahead of northern America (USA + Canada, only nine cities) in featured cities, which is often the contrast made when referring to the European concentration (e.g. Ahheier et al., 2001b, p. 7). But there can be no doubt that the data collection methodology employed here has shown that cities in the 'global South' dominate the selection. This is partly explained by the fact that NGO activity is staterelated and therefore their office networks prominently feature capital cities. In fact, 139 $(78 \%)$ of the cities featured are state capitals. Since the majority of the world's states are from the South, then the pattern of regional frequencies among our 178 cities could be merely a consequence of this attraction to capital cities. Certainly the dearth of northern American cities in our list may result from there being only two national capital cities in the region. This may also account for more cities featured from Western Europe. To take this discussion further it is necessary to consider NGO network connectivities.

NGO network connectivities have been computed for all 178 cities. This is a network measure that assesses each city in terms of the density of its links to other cities through NGOs. Thus it provides a first indication of a space of flows in the geography of global civil society. It could be, for instance, that the prevalence of Southern cities in our list includes large numbers with very low connectivities. In other words, there might still be a concentration of European cities among 
the highly connected cities. This is tested by focusing upon the distribution of just the top 50 cities (in terms of NGO network connectivity) across world regions. The result is that sub-Saharan Africa and Latin America still remain the two leading regions with 13 and 12 cities respectively. In addition, with this restricted number of cities, Pacific Asia, with seven cities, is now ahead of western Europe which features just six. This confirms reasonably conclusively that the NGO portion of the world city network is relatively biased towards poorer parts of the world.

The details of the upper echelon of NGO connectivities are illustrated in Table 1, where the top 25 cities are listed. It provides the second surprise of this analysis: this must be the first ever list of world cities headed by Nairobi! Simon (1995) has previously shown Nairobi to be important as a world city in African and Third World comparisons but not at a global level. Nairobi does appear in Glasius and Kaldor's (2002, p. 6) list of cities hosting NGOs but only in 16th position. However we should be wary of making direct comparisons with their listing for two main reasons. First, the universe of NGOs is different: their 'international and internationallyorientated NGOs' is not as restricted as the 'global NGOs' selected above. Second, their ranking only counts the number of NGOs in a city and takes no account of their office networks beyond a particular city. Thus what the results in Table 1 indicate are cities housing NGOs with

Table 1. Top 25 NGO cities by network conectivities

\begin{tabular}{|c|c|c|c|c|}
\hline \multirow[b]{2}{*}{ City } & \multicolumn{2}{|c|}{$\begin{array}{l}\text { NGO network } \\
\text { connectivity }\end{array}$} & \multicolumn{2}{|c|}{$\begin{array}{c}\text { Global network } \\
\text { connectivity }\end{array}$} \\
\hline & Level & Rank & Rank & Difference \\
\hline Nairobi & 3729 & 1 & 99 & 98 \\
\hline Brussels & 3408 & 2 & 15 & 13 \\
\hline Bangkok & 3378 & 3 & 28 & 25 \\
\hline London & 3211 & 4 & 1 & -3 \\
\hline New Delhi & 3209 & 5 & 52 & 47 \\
\hline Manila & 3198 & 6 & 46 & 40 \\
\hline Washington & 3181 & 7 & 37 & 30 \\
\hline Harare & 2999 & 8 & 132 & 124 \\
\hline Geneva & 2796 & 9 & 67 & 58 \\
\hline Moscow & 2779 & 10 & 34 & 24 \\
\hline New York & 2758 & 11 & 2 & -9 \\
\hline Mexico City & 2626 & 12 & 18 & 6 \\
\hline Jakarta & 2624 & 13 & 22 & 9 \\
\hline Tokyo & 2616 & 14 & 5 & -9 \\
\hline Accra & 2599 & 15 & 150 & 135 \\
\hline Cairo & 2569 & 16 & 59 & 43 \\
\hline Dhaka & 2562 & 17 & 152 & 135 \\
\hline Rome & 2560 & 18 & 53 & 35 \\
\hline Dakar & 2433 & 19 & 206 & 187 \\
\hline Santiago & 2408 & 20 & 57 & 37 \\
\hline Abidijan & 2326 & 21 & 131 & 110 \\
\hline \multirow[t]{2}{*}{ Buenos Aires } & 2320 & 22 & 23 & 1 \\
\hline & 2282 & 23 & 196 & 173 \\
\hline \multirow[t]{2}{*}{ Dar es Salam } & 2256 & 24 & 44 & 20 \\
\hline & 2251 & 25 & 36 & 11 \\
\hline \multicolumn{5}{|l|}{ Copenhagen } \\
\hline Beijing & & & & \\
\hline
\end{tabular}


very large office networks (i.e. the important 'interlockers' in our network model). These are the places to be for global NGOs. For their global strategies, most NGOs consider Nairobi, Bangkok, New Delhi and Manila to be at least as important as Brussels, London and Washington. Once again, European cities in general fair poorly: from 13 in Glasius and Kaldor's top 20 to only six out of 25 in Table 1.

Table 1 also reinforces the importance of capital cities to NGOs: there are only two noncapital cities in the list. However both of these cities, New York and Geneva, have special political roles through the UN organization. Thus, this emphasizes the strong propensity of NGOs to be attracted to loci of political power. Clearly global NGO location policies include the need to be placed in or near state and UN policy circles. This finding supports Chandhoke (2001) emphasis on the lack of separation of NGOs from state imperatives. It reminds us that NGOs are important as agents in global goverance as well as creators of global civil society (Rosenau, 1995; Halliday, 2000).

One big advantage of careful specification and measurement in a network analysis is that the NGO results can be compared to other similar analyses of the world city network. In particular, the office networks of 100 global service firms have been coded over 315 cities and city connectivities computed (Taylor et al., 2002a). These are termed global network connectivites because they represent the prime processes in world city network formation (Sassen, 2001; Taylor, 2004). NGO and global network connectivities are compared in Table 1. The differences really hammer home the distinctiveness of our results: only seven of the top 25 NGO cities appear in the top 25 for global network connectivity-Brussels, London, New York, Mexico City, Jakarta, Tokyo and Buenos Aires. Many very important world cities are relatively unimportant for NGO connectivity: for example Paris is only ranked 36th, Amsterdam 91st, Frankfurt 139th, Los Angeles comes in at 162nd and Chicago does not make the 178 cities in the analysis. In total contrast, many cities that are important for NGO connectivity are quite minor world cities in economic terms: for instance, the number one NGO connectivity city, Nairobi, is the leading inter-tropical African world city but it ranks only 99 for global network connectivity. This ranking difference of 98 is not untypical. There are six examples where Southern cities are ranked more than 100 places higher for NGO connectivity compared to global network connectivity: Dakar (ranking difference of 187), Dar es Salam (173), Accra and Dhaka (both 135), Harare (124) and Abidijan (110). These huge 'jumps' up the world city rankings when considering NGO networks indicate that it is cities of the Global South, especially African cities, that are much more connected than their weak positions within the world economy would imply. Quite simply, the world city network as constituted by NGO office networks really does show a new and distinctive geography of global civil society.

The importance of these findings is very clear. As we have shown previously, the emphasis on a European concentration is part of an argument that is concerned for global civil society having a very similar geographical bias to the centers of power in the global economy and global geopolitics. In other words, it has been suggested that global civil society is little more than just another projection of the power of rich countries. Framed in a network analysis, where power is more diffuse and practiced in more subtle forms (Taylor, 2002b), this disquiet for the distinctiveness of global civil society seems to be unwarranted.

\section{Conclusions}

There are two main conclusions that can be drawn from the research reported here, one practical and one methodological. 
In her assessment of the emancipatory potential of global civil society, Kaldor (2003) accepts the criticisms of Chandhoke (2001) and others that many NGOs have become too close to both governments and corporations thus compromising their radical potential. She understands this growing dissatisfaction and refers to NGOs as 'tamed' successors to earlier, more radical, social movements. However, she does not thereby conclude that global civil society is irrelevant to creating a more humane globalization. Global civil society is a process through which social contracts can be negotiated and agreements made at local, national and global scales (Kaldor, 2003, p. 107). Thus, the oft-made criticism that NGOs are undemocratic is beside the point. NGOs do not, and cannot, represent political communities in the formal democratic manner, their role is to provide political space for deliberation (Ibid., p. 140-41). They are part of an evolving global governance whereby 'parcellization of authority' is not territorial but issue-based. Thus NGOs, and other institutions, are creating a global civil society that provides a voice for individuals. They are creating a conduit for voluntary participation in global issues outside the formal political realm of the states. Of course, the Global Civil Society Yearbooks' idea of an extreme Eurocentric NGO geography runs totally counter to this global civil society process. However, it was always unlikely that such a simple geography emphasizing just one region was ever going to properly capture what is going on its this sphere of global activity. The key point that our empirical results emphasize is that the geography of global civil society is quite complex even when dealing with just one aspect of it in NGO organization. The potential diffusion of power consequent upon the network practices of NGOs is what our results are showing. The Global South is not 'represented' in any sense through NGOs but their global activities are providing a legitimizing platform for dissident and diverse voices from regions where economic and political power is lacking. Thus, our findings support Kaldor's (2003, p. 107) 'renewed hope' for developing an emancipatory global agenda.

This is an important finding based upon a set of unique results for studies of both global civil society and world cities. But we have to be very modest in our interpretations of how far we have gone along the road to understanding the geography of global civil society and the role of cities in its development. Our urban global analysis provides a fascinating glimpse of a complex geography but the results remain provisional, not in any sense definitive. This is because a quantitative, extensive research methodology can never uncover the way in which processes operate. We have proceeded on the assumption that network connections within NGO office networks are twoway processes. This is commonly disputed: for instance, Townsend et al. (2002, p. 833), following Tvedt (1998), argue that flows within NGO organizations are a one way 'transmission belt' whose basic task is to feed 'management information' up the hierarchy. In city terms, this would mean that cities of the Global South are merely transmission centers for information to be processed elsewhere. In other words, they remain 'static cities' in Jacobs's (1984) terms, with dynamic cities in the NGO portion of the world city network remaining ensconced in the North. This, of course, runs counter to Kaldor's 'renewed hope' position. But I would proffer that the extreme directed flows model is a simplistic view of how spaces of flows operate in a network society. However, the basic point is that we will only know whether this is the case when more intensive research is carried out at a global scale to complement the extensive research reported here.

\section{Acknowledgements}

The data upon which this article is based were collected by Troy Gravitt as part of his postgraduate internship at the Metropolitan Institute at Virginia Tech. Thanks are due to Troy for doing 
such a sound job and to the College of Architecture and Urban Studies at Virginia Tech for funding the internship.

\section{Appendix A: Specification of the NGO World City Network}

The NGO contribution to world city network formation can be specified as follows. This portion of the world city network is constituted by $m$ global NGOs with offices distributed across $n$ world cities. The level of activity performed by NGO $j$ in city $i$ is $z_{i j}$ which is called the activity value. The array of activity values defines a $m \times n$ activity value matrix, $Z$. A portion of the world city network is derived from this matrix using the plausible conjecture that the larger an NGO's activity value in a city, the greater the number of the NGO's flows of information, knowledge, instruction, ideas, strategies, plans, etc. will emanate from that city to other cities. This assumption allows for relations between cities to be defined.

The initial relation between each pair of cities is given by

$$
x_{a b j}=Z_{a j} \cdot Z_{b j}
$$

which describes relations between cities $\mathrm{a}$ and $\mathrm{b}$ in terms of NGO j. This defines an elemental interlock link between two cities. It is multiplicative because the potential quantity of flows between two cities rises geometrically with the quantity of activity provided in each city. From this the aggregate city interlock link between two cities can be derived as

$$
x_{a b}=\sum_{j} x_{a b j}
$$

For each city there are $n-1$ such links, one to every other city. These can be used to define the interlock connectivity of a city so that

$$
Y_{a}=\sum_{i} x_{a i} \text { where } a \neq i
$$

This measure of connectivity picks up two features of a city's activity values. First, and most obviously, cities where NGOs locate offices with higher activity values are more connected. Second, and more subtly, if those high activity offices are for NGOs with very larger office networks then the city appears more connected. In other words a city with several large offices of NGOs that themselves have small networks will not be that well connected as measured by its interlock connectivity.

Interlock connectivity indicates the importance of a city in the world city network. In the discussion that follows empirical measures of interlock connectivity is referred to as NGO network connectivity.

\section{Appendix B: Non-governmental Organizations}

\section{ActionAid}

Adventist Development and Relief Agency International

African Medical and Research Foundation 
Agency for Personal Service Overseas

Aid to the Church in Need

AMDA International

Amnesty International

Asia Institute of Management

Centre on Human Rights

Charities Aid Foundation

Christian Children's Fund

Christian Solidarity International

Committee on the Elimination of Discrimination

Commonwealth Human Rights Institution

Consumers International

Counterpart International

CUSO

Department for International Development

Dorcas Aid International

Earthwatch Institute

Food and Agricultural Organization of the United Nations

Foodfirst Information and Action Network

Ford Foundation

Freedom House

Friends of the Earth International

Friends World Committee for Consultation

German Appropriate Technology Exchange

Green Cross International

Greenpeace International

Institute of Cultural Affairs International

Intermediate Technology Development Group

International Association of Democratic Lawyers

International Association of Drilling Contractors

International Confederation of Free Trade Unions

International Cooperative Alliance

International Council of AIDS Service Organizations

International Council on Social Welfare

International Development Research Centre

International Federation of ACAT-Action by Christians for the Abolition of Torture

International Finance Corporation

International Human Rights Law Group

International Labour Organization

International League of Human Rights

International Movement Against All forms of Discrimination and Racism

International Ocean Institute

International Society for Human Rights

Islamic Relief Worldwide

Leadership for Environment and Development

No Peace Without Justice International

Opportunity International 


\author{
Oxfam International \\ Penal Reform International \\ Population Council \\ Public Services International \\ Rainforest Foundation International \\ Salvation Army \\ Save the Children \\ Shelter Now International \\ Telecommunication Development Bureau \\ UN Centre for Regional Development \\ UNICEF-United Nations Children's Fund \\ UNEP \\ United Way International \\ World Bank Institute \\ World Business Council for Sustainable Development \\ World Conference of Labour \\ World Food Programme \\ World Institute for a Sustainable Humanity \\ WHO_-World Health Organization \\ World Organization of the Scout Movement \\ World Vision International \\ World Water Council \\ World Wide Fund for Nature \\ Youth With A Mission
}

\title{
Note
}

1 The NGOs they include are all international in scope (INGOs). The discussion of NGOs in this article focuses upon their transnational activities and therefore the common synonym INGO is not used. For the empirical description and analysis in the article, a category of global NGOs is defined.

\section{References}

Anheier, H. (2001) Measuring global civil society, in Anheier, H., Glasius, M. \& Kaldor, M. (eds) Global Civil Society 2001 (Oxford: Oxford University Press), pp. 228-45.

Anheier, H., Glasius, M. \& Kaldor, M. (eds) (2001a) Global Civil Society 2001 (Oxford: Oxford University Press).

Anheier, H., Glasius, M. \& Kaldor, M. (eds) (2001b) Introducing global civil society, in Anheier, H., Glasius, M. \& Kaldor, M. (eds) Global Civil Society 2001 (Oxford: Oxford University Press), pp. 3-28.

Anheier, H. \& Themudo, N. (2002) Organizational forms of global civil society: implications of going global, in Glasius, M., Kaldor, M. \& Anheier, H. (eds), Global Civil Society 2002 (Oxford: Oxford University Press), pp. 191-216.

An-Na'im, A. (2002) Religion and global civil society: inherent incompatibility or synergy and interdependence?, in Glasius, M., Kaldor, M. \& Anheier, H. (eds), Global Civil Society 2002 (Oxford: Oxford University Press), pp. 55-76.

Castells, M. (1996) The Rise of Network Society (Oxford: Blackwell).

Chandhoke, N. (2002) The limits of global civil society, in Glasius, M., Kaldor, M. \& Anheier, H. (eds), Global Civil Society 2002 (Oxford: Oxford University Press), pp. 35-54.

Dicken, P. (2003) Global Shift (London: Paul Chapman).

Glasius, M. \& Kaldor, M. (2002) The state of global civil society before and after September 11th, in Glasius, M., Kaldor, M. and Anheier, H. (eds), Global Civil Society 2002 (Oxford: Oxford University Press), pp. 3-34.

Glasius, M., Kaldor, M. \& Anheier, H. (eds) (2002) Global Civil Society 2002 (Oxford: Oxford University Press). 
Halliday, F. (2000) Global governance: prospects and problems, Citizenship Studies, 4, pp. 311-39.

Jacobs, J. (1984) Cities and the Wealth of Nations (New York: Vintage).

Kaldor, M. (2003) Global Civil Society. An Answer to War (Cambridge: Polity).

Keane, J. (2001) Global civil society?, in Anheier, H., Glasius, M. \& Kaldor, M. (eds), Global Civil Society 2001 (Oxford: Oxford University Press), pp. 121-45.

Otto, D. (1996) NGOs in the UN system: the emerging role of international civil society, Human Rights Quarterly, 18, pp. $107-41$.

Pijl, van der K. (1998) Transnational Classes and International Relations (London: Routledge).

Roseneau, J.N. (1995) Governance and democracy in a globalizing world, in Archibugi, D., Held, D. \& Kohler, M. (eds), Re-imagining Political Community: Studies in Cosmopolitan Democracy (Cambridge: Polity), pp. 31-54.

Sassen, S. (1991) The Global City (Princeton, NJ: Princeton University Press).

Sassen, S. (1994) Cities in a World Economy (Thousand Oaks, CA: Pine Forge).

Sassen, S. (2002) Global cities and diasporic networks: microsites in global civil society, in Glasius, M., Kaldor, M. \& Anheier, H. (eds), Global Civil Society 2002 (Oxford: Oxford University Press), pp. 217-40.

Simon, D. (1995) The world city hypothesis: reflections from the periphery, in Knox, P.L. \& Taylor, P.J. (eds), World Cities in a World-Economy (Cambridge: Cambridge University Press), pp. 132-55.

Taylor, P.J. (2001) Specification of the world city network, Geographical Analysis, 33, pp. 181-94.

Taylor, P.J. (2003) Metageographical moments: a geohistorical interpretation of embedded statism and globalization, in Tetreault, M.A., Denemark, R.A., Thomas, K.P. \& Burch, K. (eds), Rethinking Political Global Economy: Emerging Issues, Unfolding Odysseys (London: Routledge).

Taylor, P.J. (2004) World City Network: a Global Urban Analysis (London: Routledge).

Taylor, P.J., Catalano, G. \& Walker, D.R.F. (2002a) Measurement of the world city network, Urban Studies, 39, pp. 2367-76.

Taylor, P.J., Catalano, G., Walker, D.R.F. \& Hoyler, M. (2002b) Diversity and power in the world city network, Cities, 19, pp. 231-41.

Townsend, J. (1999) Are non-governmental organizations working in development a transnational community?, Journal of International Development, 11, pp. 613-23.

Townsend, J., Porter, G. \& Mawdsley, E. (2002) The role of the transnational community of NGOs: governance or poverty reduction?, Journal of International Development, 14, pp. 829-39.

Tvedt, T. (1998) Angels of Mercy or Devlopment Diplomats? NGOs and Foreign Aid (Oxford: James Curry).

Peter J. Taylor is professor of geography at Loughborough University where he co-directs the Globalization and World Cities (GaWC) Study Group and Network (〈http://www.lboro.ac.uk/ gawc $\rangle$ ). An adjunct professor at the College of Architecture and Urban Studies (Virginia Tech), he is currently visiting the University of Ghent as the holder of the International Francqui Chair. His latest book is World City Network: A Global Urban Analysis (Routledge). 